\title{
Bridging the Gap: Defining the Debtor's Status during the Involuntary Gap Period
}

\author{
Joseph Mullin $\dagger$
}

The U.S. Bankruptcy Code ("the Code") seeks to achieve both efficiency and equity in allocating legal rights between debtors and creditors. In theory, the Code serves the interests of all parties by protecting the debtor's estate from both noncooperative behavior by individual creditors and dishonesty of management by the debtor. The Code accomplishes these purposes through an orderly system of claim management, with assigned priorities and substantial oversight by the bankruptcy court.

Through the procedure of involuntary bankruptcy, the Code allows creditors to force a debtor into bankruptcy when the debtor fails to pay debts as they come due. ${ }^{2}$ Creditors rely on this provision primarily when they believe that a debtor may dissipate the estate through dishonesty or incompetence. Although both voluntary and involuntary bankruptcies are governed by the same provisions once the court orders a debtor into bankruptcy, the involuntary procedure leaves a "gap period" between the filing of the involuntary petition and the court's decision to order relief. ${ }^{3}$ Under current law, the ability of the "gap debtor" to execute certain business operations is uncertain. This uncertainty may threaten the viability of the debtor's business, despite the lack of any action by the bankruptcy court. In addition, the ambiguity of the gap period affects certain ordinary business agreements that feature arrangements contingent on the debtor's insolvency. ${ }^{5}$

† B.A. 1992, Georgetown University; J.D. Candidate 1995, The University of Chicago.

1 Bankruptcy Act of 1978, Pub L No 95-598 (1978), codified at 11 USC $\S 101$ et seq (1988 \& Supp 1992).

2 See 11 USC $\S 303(\mathrm{~h})$.

3 If the bankruptcy court approves the involuntary petition and orders the debtor into bankruptcy, it issues an "order for relief." Otherwise, it dismisses the petition. 11 USC \& 303.

"The term "gap debtor" will be used in this Comment to mean the debtor during the period between the filing of an involuntary petition and the final order for relief. "Gap creditor" means a creditor during the same period.

5 The significance of the bankruptcy rules is not limited to financially troubled enti- 
This Comment maintains that neither creditor nor debtor interests are served by ambiguity in the scope of permissible debtor behavior during the gap period. The content of these legal rules is also significant because it will affect the incentives governing debtor-creditor relations, both before and after filing the petition. Although involuntary bankruptcies account for only a small percentage of total bankruptcies, ${ }^{6}$ they may be more likely to involve significant assets. ${ }^{7}$ In addition, many private creditor-debtor settlements may result from threats of involuntary proceedings. ${ }^{8}$ The precarious position of a gap debtor thus presents an opportunity for individual creditors to exploit a vulnerable debtor's position with threats of an involuntary petition, coercing deals that favor individual creditor interests over those of the estate as a whole.

The Code fails to delineate the respective rights of creditors, the debtor, and those who conduct business with the debtor during the gap period. This Comment argues that debtors should have the authority to issue secured debt for reasonably equivalent value during the gap period without court approval. This position is consistent with the Code's language as well as its overall purpose of preserving the viability of the debtor's business. Requiring court approval could threaten the survival of the gap debtor's business by upsetting already fragile commercial relationships. It would also violate basic notions of fairness, since the petition filed is not an authoritative disposition of the debtor's suitability for bankruptcy.

ties. For example, large commercial banks frequently enter into liquidity agreements with issuers of asset-backed commercial paper in which the banks agree to lend money to fulfill the issuers' cash-flow obligations. Moody's Investors Services, Inc., a powerful bond rating agency, has recently begun to insist that banks agree to continue to lend money on a secured basis for 30 days into the gap period. Public Finance Bankers Upset: Say Moody's Criteria Changed, Global Guaranty 1 (June 21, 1993). This is one example of an "outsideof-bankruptcy" commercial relationship that must consider the possibility of an involuntary filing.

6 See Lynn M. Lopucki, Strategies for Creditors in Bankruptcy Proceedings $\$ 2.8$ at $77 \mathrm{n} 1$ (Little, Brown, 2d ed 1991); Robin E. Phelan and Mark X. Mullin, Involuntary Bankruptcy, in Daniel R. Cowans, 2 Cowans Bankruptcy Law and Practice ch 14, § 14.1 at 697 (West, 1989). One explanation for the small number of involuntary filings is that there is a collective action problem preventing individual creditors from expending resources to file the petition where the benefit inures to the entire creditor pool.

7 Phelan and Mullin, Involuntary Bankruptcy $\$ 14.1$ at 698 . Because filing an involuntary petition is more expensive to individual creditors than a voluntary petition, it is likely that more substantial assets are available in involuntary bankruptcies-otherwise, the involuntary petition would not be worthwhile.

${ }^{8}$ See Lopucki, Strategies for Creditors $\$ 2.16 .4$ at 126-30. 
Section I of this Comment introduces the statutory provisions applicable to an involuntary bankruptcy and explains the particular importance of clarifying the law that governs the gap period. Section II examines the significant unresolved issues of secured lending and court approval that a debtor confronts while attempting to continue business operations during the gap period. It then discusses the inadequacy of current court treatment of the gap period. Finally, Section III proposes a new approach to the gap period problem that better serves the Code's twin goals of efficiency and equity.

\section{THE CURRENT STATE OF THE LAW}

\section{A. Statutory Background}

This subsection describes the statutory provisions applicable to involuntary bankruptcies, highlighting ambiguities in the Code that hinder the gap debtor's ability to enter into potentially beneficial transactions.

\section{Section 303: the involuntary petition.}

Section 303 of the Code describes the procedures through which a debtor may be forced into bankruptcy, and to some extent establishes the duties and powers of the debtor during the gap period. ${ }^{9}$ Under $\$ 303$, creditors may file an involuntary bankruptcy petition under Chapter 7 (liquidation) ${ }^{10}$ or Chapter 11 (reorganization). ${ }^{11}$ Filing creditors must themselves meet certain prerequisites in number and aggregate claim amount, ${ }^{12}$ although courts are often flexible in enforcing these requirements. ${ }^{13}$ The debtor may contest the bankruptcy petition, and

9 See 11 USC $\S 303$.

1011 USC $\S 801$ et seq.

1111 USC $\$ \S 1101$ et seq.

1211 USC $\$ 303(\mathrm{~b})(1)$ requires at least three petitioning creditors whose debts aggregate at least $\$ 5,000$ in unsecured debt. The debts may not be contingent or subject to a bona fide dispute. If there are fewer than 12 creditors, special provisions allow for a single petitioning creditor. 11 USC $\S 303(\mathrm{~b})(2)$.

${ }^{13}$ See, for example, In re Molen Drilling Co., Inc., 68 Bankr 840 (Bankr D Mont 1987). In Molen Drilling, two of the three petitioning creditors sought to withdraw because they claimed they had been misled by the third. Id at 842 . The court refused their request, reasoning that "the Court may not permit a petitioning creditor to withdraw if to do so would defeat the petition." Id. See also In re Hutter Associates, Inc., 138 Bankr 512, 516 (W D Va 1992) (holding that defects in the number of petitioning creditors may be waived when the debtor fails to answer, and that such defects do not deprive the bankruptcy court of subject matter jurisdiction). 
the court will determine whether "the debtor is generally not paying" debts as they become due "unless such debts are the subject of a bona fide dispute ...."14 The period between the filing of the petition and the court's determination is known as the involuntary gap period.

The length of the gap period depends upon both the court calendar and the vigilance of the parties in pursuing their case. Bankruptcy Rule 1013(a) provides that "[t]he court shall determine the issues of a contested petition at the earliest practicable time and forthwith enter an order for relief, dismiss the petition, or enter other appropriate orders. ${ }^{15}$ This rule, however, does not guarantee a speedy adjudication of the debtor's status. Gap periods have lasted over two years. ${ }^{16}$ A survey of dismissed involuntary petitions found an average gap period of over a year. ${ }^{17}$ Such an extended gap period accentuates the importance of clarifying the rights and responsibilities of the gap debtor.

1411 USC $\S 303(d),(h)(1)$. This test is often denoted "equity insolvency" and is distinguished from the traditional bankruptcy notion of balance-sheet insolvency, which compares total assets to total liabilities. For a discussion of the debate surrounding the equity and balance-sheet definitions of insolvency, see John C. McCoid II, The Occasion for Involuntary Bankruptcy, 61 Am Bankr L J 195 (1987). See also Lawrence Ponoroff, Involuntary Bankruptcy and the Bona Fides of a Bona Fide Dispute, 65 Ind L J 315, 329 (1990).

The "generally not paying debts" calculation is a question of fact for the bankruptcy court. It "requires a more general showing of [a] debtor's financial condition and debt structure than merely establishing the existence of a few unpaid debts." In re Dill, 731 F2d 629, 632 (9th Cir 1984). In 1984, Congress added the language excepting claims subject to a "bona fide dispute" from the "generally not paying" determination. Pub L No 98-353, $\S 426$ (b), 98 Stat 333, 369 (1984). For a discussion of the bona fide dispute exception added by Congress in 1984, see In re Rimell, 946 F2d 1363, 1365-66 (8th Cir 1991), cert denied as Rimell $v$ Mark Twain Bank, 112 S Ct 2275 (1992). See also In re CLE Corporation, 59 Bankr 579, 584-85 (Bankr N D Ga 1986) (finding that "creative defenses" to petitioning-creditor claims were not in good faith but were raised solely to defeat the involuntary petition); In re Rubin, 769 F2d 611, 614-15 (9th Cir 1985) (concluding that the undisputed-claims requirement is not jurisdictional, but rather a substantive element of the petitioning creditor's case to be proved at trial); Ponoroff, 65 Ind L J 315.

1511 USC Appendix, Rule 1013(a).

${ }^{16}$ See, for example, In the Matter of R.C. Wynn, 889 F2d 644, 645 (5th Cir 1989) (25 months). The court, however, blamed the debtor for the delay, commenting that "he gained a windfall by the delay and should be thankful that a trustee was not placed in charge of his assets earlier." Id at 646.

${ }_{17}$ The sample was drawn from the Prentice Hall Public Records-Combined Bankruptcy Filings database compiled by Prentice Hall Legal Financial Services. The set of cases included 515 involuntary petitions from selected states that were added to the database during 1988 and 1989 . Of the 515 involuntary cases filed in that period, 205 had been dismissed. Forty of those were selected at random. The mean gap period of the sample was 12.7 months, with a standard deviation of 12.2 months. The results highlight the variability of gap periods among districts with periods ranging from as low as one month to as high as 48 months. In Texas, which represented half of the sample, the average gap period was 18.3 months, with a standard deviation of 14.3 months. 
As a protective measure, the court is authorized to "require the petitioners ... to file a bond to indemnify the debtor" for court costs and attorneys' fees upon dismissal. ${ }^{18}$ In the case of a bad faith filing, the court may award compensatory and punitive damages to the debtor. ${ }^{19}$ The legislative history of this provision reveals an appreciation for the debtor's predicament:

The bonding requirement will discourage frivolous petitions as well as spiteful petitions based on a desire to embarrass the debtor (who may be a competitor of a petitioning creditor) or to put the debtor out of business without good cause. An involuntary petition may put a debtor out of business even if it is without foundation and is later dismissed. ${ }^{20}$

The court is also authorized, upon the motion of a party in interest, to appoint an interim trustee during the gap period in Chapter 7 cases "if necessary to preserve the property of the estate or to prevent loss to the estate."21

The clearest expression of Congressional intent to authorize the gap debtor to continue normal business operations is found in § 303(f), which provides:

Notwithstanding section 363 of this title, except to the extent that the court orders otherwise, and until an order for relief in the case, any business of the debtor may continue to operate, and the debtor may continue to use, acquire, or dispose of property as if an involuntary case concerning the debtor had not been commenced. ${ }^{22}$

Although the sweeping language of this provision implies that the filing of an involuntary petition does not restrict the gap debtor, a careful reading indicates otherwise. Because $\S 303(f)$ specifically mentions only $\S 363$, it arguably may exempt the gap debtor only from $\S 363$, rather than from all the restrictions of the Code. Indeed, this would be entirely logical; $\S 363$ imposes stringent notice and court approval requirements on debtors, and thus it would be difficult, if not impossible, for many gap debtors to function normally if they were bound by the strictures of $\S$ 363. ${ }^{23}$ Despite disagreement over the scope of the exemption,

18 See 11 USC \& 303(e), (i)(1).

19 See 11 USC \& 303(i)(2).

20 Bankruptcy Reform Act of 1978, S Rep No 95-989, 95th Cong, 2d Sess 33 (1978), reprinted in 1978 USCCAN 5787, 5819.

2111 USC \& $303(\mathrm{~g})$.

2211 USC § 303(f).

23 For instance, $\S 363$ prohibits the trustee from using, selling, or leasing property of 
however, the intent to relieve the gap debtor from burdensome restrictions is unmistakably clear.

\section{The interplay between $\S 362$ and $\S 549(\mathrm{~b})$.}

Section 362 of the Code presents further complications for the gap debtor, as it appears to forbid such debtors from obtaining secured credit. Section 362 automatically enjoins, in both voluntary and involuntary petitions, proceedings by most creditors against the debtor's assets. ${ }^{24}$ The automatic stay provision is critical because it prevents a "race to the debtor's assets"-one of the central problems that the bankruptcy law seeks to avoid. ${ }^{25}$ Section 362 may hamper the debtor's business, however, since it "operates as a stay, applicable to all entities, of ... (4) any act to create, perfect, or enforce any lien against property of the estate ...."26 Strict application of $\S 362(a)(4)$ would therefore foreclose the debtor's opportunity to obtain credit through secured borrowing - even if such borrowing arose in the ordinary course of the debtor's business.

Section 362 is apparently superseded by $\S 549(\mathrm{~b}),{ }^{27}$ which imposes limitations upon one of the avoidance powers that the trustee may exercise after issuance of the order for relief: the ability to rescind a post-petition transfer of estate property. ${ }^{28}$

the estate outside the ordinary course of business absent notice and a hearing. See 11 USC $\S 363(\mathrm{~b})$. For business in the ordinary course, the trustee is generally authorized to complete such transactions without notice and a hearing; however, the court reserves the right to order otherwise. See 11 USC $\S 363$ (c). In addition, creditors with an interest in the property of the estate may request court supervision of the use of such property. See 11 USC \& 363(e).

${ }^{24}$ This injunction is effective during the involuntary gap period because the creditor's act of filing a petition triggers the $\$ 362$ automatic stay.

${ }_{25}$ Secured creditors, for example, will be prevented from exercising their repossession rights upon default. See 11 USC $\S 362(a)(3)-(5)$.

${ }_{28} 11$ USC $\$ 362(a)(4)$. The term "'entity' includes person, estate, trust, governmental unit, and United States trustee." 11 USC $\S 101(15)$.

${ }_{27}$ Section $549(\mathrm{~b})$ only apparently supersedes $\$ 362$ because they are both facially valid Code provisions that cannot be reconciled. Additionally, the sections are imprecisely focused on two different situations. Section 362(a)(4) prohibits the act of lien creation, while $\S 549(\mathrm{~b})$ provides a defense to an avoidance action by the trustee. For a discussion of the statutory and policy reasons why $\$ 549(\mathrm{~b})$ should dominate the dispute, see text accompanying notes 70-75.

${ }_{23} 11$ USC \& 549(a) creates one of the several "avoiding powers" of the trustee. In addition to $\S 549$, which governs post-petition transfers, there is $\S 544$, which provides the trustee with the "strong-arm" power of a hypothetical lien creditor; $\$ 547(b)$, which applies to preferential transfers; and $\S 548$, which bars fraudulent conveyances. If a transfer is avoided under any of these sections, the trustee may recover from the transferee the property transferred or its value pursuant to $\S 550(\mathrm{a})$. For a detailed discussion of the purposes and scope of the avoiding powers, see Thomas H. Jackson, Avoiding Powers in 
Section 549(b) excepts from the post-petition avoidance power

a transfer made after the commencement of [an involuntary] case but before the order for relief to the extent any value, including services, but not including satisfaction or securing of a debt that arose before the commencement of the case, is given after the commencement of the case in exchange for such transfer, notwithstanding any notice or knowledge of the case that the transferee has. ${ }^{29}$

Thus, a gap debtor should arguably be able to transfer property (including the grant of a security interest in property ${ }^{30}$ ) notwithstanding the limitations of $\S 362$. Furthermore, a secured gap creditor should obtain all of the benefits of a secured lender whether inside bankruptcy (following the order for relief) or outside of bankruptcy (following dismissal of the petition).

\section{Priority in bankruptcy: $\S 502$ and $\S 507$.}

Sections 502(f) and 507 of the Code, which respectively describe the allowance and priority of certain claims or interests, introduce an additional statutory complication to involuntary cases. Together with other sections of the Code, they establish a hierarchical priority system, effectively dividing the debtor's assets into four levels of priority claims relevant to this Comment. ${ }^{31}$ The first priority is given to holders of non-avoided property rights-principally, fully secured creditors. ${ }^{32}$ Following satisfaction of these property interests, the Code grants next priority to administrative expenses incurred in preserving the estate. ${ }^{33}$

Bankruptcy, 36 Stan L Rev 725 (1984).

${ }_{29} 11$ USC $\S 549(\mathrm{~b})$ (emphasis added). Although inartfully worded, $\S 549(\mathrm{~b})$ is effectively a defense against the avoiding powers of the trustee that arise following the order of relief. Recognizing that Congress almost certainly intended $\$ 549(\mathrm{~b})$ to exempt the gap period from $\S 549(a)$, courts have corrected Congress's likely drafting error. See, for example, In re Rainbow Music, Inc., 154 Bankr 559, 562 (Bankr N D Cal 1993).

${ }^{30} 11$ USC \& 101 provides that “transfer' means every mode ... of disposing of or parting with property or with an interest in property, including retention of title as a security interest...."

31 For simplicity, this Comment ignores the remaining levels of priority, which are unaffected by the policies discussed. For example, $\S 726(\mathrm{~b})$ subordinates administrative expenses incurred under Chapter 11 to Chapter 7 administrative expenses incurred following the conversion of a case from reorganization to liquidation.

${ }^{32}$ See 11 USC $\$ 725$.

33 See 11 USC $\$ 507(a)(1)$. First-priority administrative expenses primarily consist of the "actual, necessary costs and expenses of preserving the estate, including wages, salaries, or commissions for services rendered after the commencement of the case ...." 11 USC $\S 503(b)(1)(A)$. Gap claims under $\S 502(f)$ are explicitly excluded from the list of qual- 
Once these claims are satisfied in full, priority passes to "unsecured claims allowed under section 502(f) of [the Code]."34 Claims in this category are referred to as second-priority expense claims. Finally, several other miscellaneous claims receive special treatment under $\S 507^{35}$ before the estate is divided pro rata among the unsecured creditors pursuant to $\S 726 .^{36}$

Section 502(f) states that "in an involuntary case, a claim arising in the ordinary course of the debtor's business or financial affairs [during the gap period] shall be determined ... the same as if such claim had arisen before the date of the filing of the petition."37 The net effect of $\S 502(f)$, then, is to give a gap debtor's unsecured creditors second-priority expense claims. ${ }^{38}$ In many cases, there may not be significant assets remaining at this level, particularly if the first-priority administrative expenses are expected to be large. Subordination of $\S 502(f)$ claims to firstpriority administrative expenses thus hinders the gap debtor's ability to obtain unsecured credit.

Even if the debtor can assure gap creditors that funds will be available for the satisfaction of second-priority claims, the $\S 502(f)$ requirement that claims arise "in the ordinary course of business" further limits the gap debtor's ability to obtain credit. ${ }^{39}$ Courts use either of two tests to decide whether a transaction occurs in the ordinary course of business: the horizontal test or the vertical test. The horizontal, or industry-wide, test involves a "comparison of this debtor's business to other like businesses."

ifying administrative expenses. 11 USC § 503(b).

${ }^{34}$ See 11 USC $\$ 507(a)(2)$.

${ }^{35}$ See 11 USC $\S 507(a)(3)-(8)$. The claims that follow second-priority expense status in $\S 507$ (a) are, in order: certain allowed unsecured claims for wages, salaries, or commissions; specified allowed unsecured claims for contributions to an employee benefit plan; the allowed unsecured claims of grain producers and fishermen; allowed unsecured claims of individuals for purchases made for personal, family, or household use; certain allowed unsecured claims of governmental units; and allowed unsecured claims based on commitments to the Federal Deposit Insurance Corporation, the Resolution Trust Corporation, the Office of Thrift Supervision, the Comptroller of the Currency, or the Federal Reserve Board. Id.

${ }^{36}$ See 11 USC \& 726(a) and (b).

${ }^{37} 11$ USC § 502(f).

${ }^{38}$ In re Advanced Electronics, Inc., 107 Bankr 503, 505-06 (Bankr M D Pa 1989), offers a paradigmatic case of $\S 502(f)$ ordinary course expenses. The court treated the gapperiod wage claims of the debtor's employees as second-priority expenses. Id.

${ }^{39}$ The concept of ordinary-course business expenses is used throughout the Code. This Comment assumes that "ordinary course" has a consistent application in the relevant Code sections. Consistency is an important feature for certainty in Code interpretation. See Dewsnup v Timm, 112 S Ct 773, 786-88 (1992) (Scalia dissenting).

${ }^{10}$ In re Johns-Manville Corp., 60 Bankr 612, 618 (Bankr S D NY 1986). This case 
The vertical, or creditor's expectation, test looks to whether the transaction subjects a hypothetical creditor to an economic risk not anticipated when extending credit to the debtor. ${ }^{41}$

Both tests place serious restrictions on the ability of the gap debtor to engage in conduct outside the scope of normal, everyday business transactions. In In re Lite Coal Mining Co., ${ }^{42}$ a voluntary case, the court found that the extension of large amounts of credit during a bankruptcy proceeding did not occur in the ordinary course of business, where the coal-mining debtor:

used the post-petition loans to purchase numerous expensive items of equipment, yet ... mined only 4,000 to 5,000 tons of coal during the course of their post-petition business, at a mine site where it never even obtained a signed or complete lease. $^{43}$

This standard provides little solace to the gap debtor or to potential creditors because it relies not only on the preexisting relationship between the parties, but also on the ability of the gap debtor to continue operations. The standard may also require a gap debtor to decline an opportunity that does not fall clearly within the bounds of prior activity, even though the opportunity would allow a beneficial extension of the debtor's business.

One particularly important expense outside the ordinary course of business is attorneys' fees. In In re Manufacturer's Supply Co., the president of a Chapter 7 debtor sought reimbursement of $\$ 2,000$ he had advanced the debtor during the involuntary gap period to pay counsel's retainer. ${ }^{44}$ The court found the transaction was outside the ordinary course of business and,

held that hiring political lobbyists was in the ordinary course of business of a large Fortune 500 mining, manufacturing, and production company where a substantial number of similar companies routinely lobbied Congress. Id at 613, 618-19.

11 Id at 616. The test has also been phrased as "whether "the transaction is within the day-to-day business of the debtor without some kind of separate authorization." Id at 617, quoting In re Waterfront Companies, Inc., 56 Bankr 31, 35 (Bankr D Minn 1985). This almost necessarily involves looking at the debtor's pre-petition business practices. JohnsManville, 60 Bankr at 617 . The Johns-Manville court reasoned that the debtor's prior lobbying efforts would alert the creditors that the debtor would likely continue to engage in these activities and might even find the need to expand its lobbying efforts. Id at 61819.

12122 Bankr 692 (Bankr N D W Va 1990).

13 Id at 695 (citation omitted). See also In re Lockwood Enterprises, Inc., 52 Bankr 871 (Bankr S D NY 1985). In Lockwood, the court refused to classify money borrowed to meet payroll and operating expenses as an ordinary-course expense, because there was no evidence that such borrowing was the debtor's pre-petition practice. Id at 874 .

132 Bankr 127, 127-28 (Bankr N D Ohio 1991). 
therefore, not entitled to either administrative-expense or secondpriority status..$^{45}$ In In re Hanson Industries, Inc., the court classified the majority of the gap debtor's legal bills (and all those expended in combatting the involuntary petition) as general unsecured claims since they arose outside of the ordinary course of business. ${ }^{46}$ This hostility to offering financial protection for an unsuccessful debtor's counsel during the gap period suggests that counsel will either demand an immediate retainer (which requires cash on hand $)^{47}$ or work only on a contingency fee basis. ${ }^{48}$ This situation raises doubts about the gap debtor's ability to mount an effective defense, even when its position is meritorious.

\section{Does the gap debtor qualify as a trustee under $\S 364$ ?}

The most controversial statutory ambiguity confronting a Chapter 11 gap debtor concerns the applicability of provisions that do not specifically mention involuntary debtors, but rather refer generally to the trustee. The fundamental question is whether a gap debtor qualifies as a debtor-in-possession and thus has the powers and responsibilities of a trustee..$^{49}$ If so, the gap debtor, as trustee, will assume substantial burdens, ${ }^{50}$ but will also realize significant benefits.

The most significant of these advantages comes from $\S 364$, which grants the trustee expansive power to obtain post-petition credit if it first receives court approval. ${ }^{51}$ In addition to the $\S$ 364(a) authorization of unsecured debt in the ordinary course of business (a provision not applicable to the gap debtor), $\S 364$ (c) provides that the court may authorize the obtaining of credit: "(1)

45 Id at 128-29.

4690 Bankr 405, 413-17 (Bankr D Minn 1988).

47 A retainer also provides inadequate financial protection since it is a transfer of money in exchange for the promise of future services.

4890 Bankr at 416-17. Upon successful defense against a petition, debtor's counsel would take a percentage of the judgment against petitioners under $\S 303(i)$.

49 In voluntary cases filed under Chapter 11 , the debtor normally retains its current management, at least initially. In such a case, where no qualified person is serving as trustee and the debtor is left in possession of its business and property, $\$ 1101$ declares the debtor a "debtor-in-possession." Section 1107 provides that a debtor-in-possession shall have the rights, powers, and responsibilities of a trustee.

so See generally Raymond T. Nimmer and Richard B. Feinberg, Chapter 11 Business Governance: Fiduciary Duties, Business Judgment, Trustees and Exclusivity, 6 Bankr Dev J 1 (1989).

${ }^{51}$ See 11 USC $\$ 364$. For a general discussion of $\$ 364$ as it applies to Chapter 11 reorganizations, see Comment, Extending Post-Petition Credit to Reorganizing Debtors: Understanding the Tricks and Traps of Bankruptcy Code Section 364, 1990 Utah L Rev 93. 
with priority over any or all administrative expenses ...; (2) secured by a lien on property of the estate that is not otherwise subject to a lien; or (3) secured by a junior lien on property of the estate that is subject to a lien. ".52 Section 364(d) also empowers the court to grant a senior lien on encumbered property if the trustee is otherwise unable to obtain credit and if adequate protection is afforded the lien creditor. In addition to the protection of the automatic stay, the enhanced prospect of obtaining credit under $\S 364$ creates a significant incentive for firms to enter bankruptcy. ${ }^{53}$ Qualifying as a trustee will greatly enhance the gap debtor's ability to obtain credit. ${ }^{54}$

\section{Summary.}

The provisions of the Code that govern involuntary bankruptcies set forth the basic mechanics of commencing an involuntary bankruptcy proceeding, but also produce considerable ambiguity concerning the debtor's ability to conduct business during the gap period. First, $\S 303(f)$ seems to reflect a Congressional desire to leave the gap debtor largely able to continue normal business operations. However, the fact that the section specifically exempts the debtor only from the constraints of $\S 363$ suggests that the gap debtor's power may be nearly as curtailed as that of the voluntary debtor. Second, the interplay of $\$ \S 362$ and 549(b) jeopardizes the ability of the gap debtor to obtain secured credit. Third, the courts' varying treatment of the "ordinary course of business" requirement of $\S 502(f)$ severely curtails the gap debtor's ability to obtain any credit. Finally, resolving the question whether a gap debtor qualifies as a trustee would have substantial effects on the debtor's powers during the gap period.

\section{B. Policy Issues}

The description of the costly ambiguities in the Code's treatment of gap debtors reveals where the Code could stand improve-

5211 USC § 364(c).

53 See Michelle Singletary, Buoyed by Bankruptcy: A Rising Number of Firms Are Using the Courts to Keep Afloat, Wash Post D11 (Feb 6, 1992) ("Unlike most consumers who find it hard to get credit after filing for bankruptcy protection, many companies are able to borrow from banks and are increasingly using bankruptcy as a major financing tool.").

54 The potential trustee status of the gap debtor implicates several other Code provisions, including $\$ 365$, which empowers the trustee, with court approval, to assume or reject any executory contract or unexpired lease of the debtor. This and other provisions are at least facially inconsistent with § 303(f). 
ment. The following discussion of policy concerns relating to the gap debtor's status provides some suggestions as to why and how the gap debtor's powers should be specified. The debtor's status during the involuntary gap period raises several policy questions that animate the analysis of this Comment. Consideration of these questions depends upon the purpose and ideal timing of the involuntary petition. ${ }^{55}$

The vast majority of bankruptcies are voluntary. ${ }^{56}$ There are a number of explanatory theories, but the prevailing view is that creditors are just as reluctant as debtors to enter into bankruptcy. Major creditors know that the debtor's business depends upon its reputation, and that it will have great difficulty operating after the filing of the involuntary petition. ${ }^{57}$ Creditors may thus prefer to postpone filing an involuntary petition in order to maximize the value of the estate and perhaps avoid a significant loss. Individual creditors, however, may place their interests above those of the estate as a whole and force the debtor into bankruptcy. ${ }^{58}$ The direct and indirect costs of a bankruptcy filing ${ }^{59}$ suggest that bankruptcy should be avoided whenever the

55 For a more detailed discussion, see Thomas H. Jackson, The Logic and Limits of Bankruptcy Law 193-208 (Harvard, 1986).

${ }_{56}$ In 1983, for example, involuntary petitions accounted for 1,804 of the 349,232 total bankruptcy filings, 58,986 of which were business bankruptcies. Statistical Analysis Division, United States Bankruptcy Courts, Table F-2A (1984), cited in Jackson, The Logic and Limits of Bankruptcy Law at $206 \mathrm{n} 42$.

${ }^{57}$ See Phelan and Mullin, Involuntary Bankruptcy $\$ 14.1$ at 697-98 (cited in note 6).

ss Although the collective interests of the creditors should govern the court's decision as to whether to grant an order for relief, the ability of non-petitioning creditors to protect their interests is extremely limited. In In re Royal Gate Associates, Ltd., 81 Bankr 165, 167 (Bankr M D Ga 1988), the court stated that "[a] creditor does not have standing to oppose an involuntary bankruptcy petition."

${ }^{59}$ See Edward I. Altman, A Further Empirical Investigation of the Bankruptcy Cost Question, 39 J Finance 1067 (1984). Altman conducted an empirical study of direct and indirect bankruptcy costs in voluntary proceedings. Direct bankruptcy costs include "legal, accounting, filing and other administrative costs." Id. Indirect costs include managerial opportunity costs and the loss of sales and profits when potential buyers perceive that default is likely, and the higher cost of credit or inability to obtain credit. Id at 1071. "On average, bankruptcy costs ranged from $11 \%$ to $17 \%$ of firm value up to three years prior to bankruptcy." Id at 1087. See also Banks and Bankruptcy: So Long, Old Buddy, The Economist 83 (Feb 8, 1992), which adds that other bankruptcy costs include "the potential loss of valued customers and employees, the distraction of management, and the court's influence on operating decisions." For an empirical example demonstrating that a reorganization need not result in excessive bankruptcy costs, see Steven N. Kaplan, Federated's Acquisition and Bankruptcy: Lessons and Implications (unpublished 1994) (on file with U Chi L Rev). 
debtor suffers only from a temporary liquidity problem $^{60}$ or where a non-bankruptcy restructuring is possible. ${ }^{61}$

Some involuntary filings, however, are desirable. Under certain circumstances, the involuntary petition is a necessary measure to forestall a destructive race to the debtor's assets. For example, a secured creditor may intend to exercise its foreclosure power to repossess essential property. Other creditors may quickly follow, fearing their claims will disappear. The debtor could be unwilling or unable to object. It is important, therefore, that creditors have some mechanism to prevent such a race.

A related concern involves debtor misbehavior. All parties should encourage the debtor to behave in a manner that will maximize estate value. In some cases, however, it may be diffcult to differentiate between maximizing actions and preferential transfers. ${ }^{62}$ A practical approach to the gap period must accommodate the legitimate interests of creditors by reining in debtor behavior without violating the equitable rights of the debtor to salvage its business.

The final general policy issue concerns the relationship between voluntary and involuntary petitions. Since most bankruptcies are voluntarily initiated by the debtor, involuntary bankruptcies are open to a variety of interpretations. They may be seen as purely aberrational, as a failure of the system to provide for the preferred bankruptcy procedure, or as a successful response to a specific, but relatively rare set of circumstances. Conversely, the existence of the involuntary petition undoubtedly gives a creditor leverage to push the debtor into voluntary bankruptcy and can be an important factor in pre-bankruptcy negotiations. Voluntary and involuntary bankruptcies need not receive perfectly parallel treatment, but it is important that they serve their respective

60 Some financial economists consider this a specious argument, because if the debtor faced simply a short-term liquidity problem, the debtor should be able to generate the necessary liquidity in the capital markets. See Jackson, The Logic and Limits of Bankruptcy Law at 198 (cited in note 55). Such an argument, however, relies on a stylized view of efficient capital markets that may not be applicable to all debtors. The most significant barrier for the gap debtor may be that the firm's true value is private, nonverifiable information preventing the debtor from effectively accessing the capital markets.

${ }_{61}$ But see Olympia Equipment Leasing Co. $v$ Western Union Telegraph Co., 786 F2d 794, 802-03 (7th Cir 1986) (Easterbrook concurring). Judge Easterbrook argues that the majority of bankruptcy costs are associated with financial distress rather than formal bankruptcy proceedings. As a result, non-bankruptcy restructuring may be just as costly, or more so, than actual bankruptcy. Judge Easterbrook does not, however, consider the costs of either process to be unduly restrictive. Id.

${ }^{62}$ Section 547 outlines the trustee's power to avoid preferential transfers. See note 28. 
purposes in a manner consistent with common bankruptcy goals. To that end, the ambiguity of the gap period is destructive because it prevents involuntary bankruptcy from being an attractive option in those cases in which it is, in fact, the best alternative. Courts should interpret the involuntary gap in accordance with these policy concerns by taking into account the dynamic effect that involuntary bankruptcy rules have on voluntary bankruptcies and business relations.

Moving beyond the abstract policy concerns, the most important practical problem lies in identifying the optimal level of credit which should be available to the debtor for investment during the gap period. Unless the involuntary petition is entirely frivolous, gap debtors will be experiencing some level of economic or financial distress. The debtor's incentives are to continue to operate the business so as to retain control and maximize residual value, inside or outside of bankruptcy. Bankruptcy proceedings, however, may hamper the debtor's ability to finance positive net present value projects and may therefore result in underinvestment. ${ }^{63}$ Although creditors also seek to maximize firm value, they recognize that providing credit to the debtor will create additional claimants, thereby reducing their pro-rata share. ${ }^{64}$ If granted second priority under $\S 507(a)(2)$, the gap creditors will be even more destructive to petitioning creditor interests. Pre-petition creditors will also be concerned by the debtor's incentive to engage in risky projects that have a negative net present value. ${ }^{65}$

This conflict between debtors and creditors is a standard agency problem associated with capital structure, but the conflict intensifies during insolvency. ${ }^{66}$ Generally, all interested parties should agree to the expenditure of additional resources on a positive net present value project. Problems arise to the extent the debtor has perverse incentives to gamble the estate's residual value on an overly risky project. However, the presence of parties willing to invest new resources into the business following the

63 See Robert Gertner and David Scharfstein, A Theory of Workouts and the Effects of Reorganization Law, 46 J Finance 1189, 1191 (1991).

64 See 11 USC $\S 726$.

65 This problem is commonly called "risk alteration." For a discussion of this issue, see William A. Klein and John C. Coffee, Jr., Business Organization and Finance: Legal and Economic Principles 326-30 (Foundation, 4th ed 1990). For numerical examples and game theoretic analysis of debtor and creditor misbehavior, see Randal C. Picker, Security Interests, Misbehavior, and Common Pools, 59 U Chi L Rev 645 (1992).

${ }_{66}$ See George G. Triantis, A Theory of the Regulation of Debtor-in-Possession Financing, 46 Vand L Rev 901, 912-14 (1993). 
filing of an involuntary petition suggests that the "new" investors have made an independent evaluation of the proposed use of the new credit and will have proper monitoring incentives. ${ }^{67}$

These questions have not been the subject of extensive litigation or scholarship, nor is there an explicit or recognized disagreement among the federal courts. What is apparent, both from the cases which have arisen and the Code itself, is that a number of unresolved issues confront debtors and creditors involved in an involuntary proceeding, potential debtors and creditors who must anticipate the gap period, and ultimately, the courts that must resolve the conflicts. In such a sparsely litigated area, Congress is unlikely to have considered the complexity of these statutory ambiguities. It is therefore particularly important to consider the policy arguments in support of each position. These policy concerns operate on two levels: system-wide concerns, and optimal incentives for individual bankruptcy cases. The former include averting a destructive race to the assets, preventing debtor misbehavior, and insuring equitable treatment for debtors and creditors. The latter include the practical problems of obtaining necessary credit for ongoing business operations and preventing frivolous or strategic involuntary filings.

\section{ApProaches to SECURED BorRowing AND CoURT APPROVAL}

The major unresolved issue confronting a gap debtor concerns its authority to grant a security interest in property (or otherwise transfer property) during the gap period without obtaining prior court approval. It is upon this specific issue that the remainder of this Comment will focus. The issue is critical because of the unattractiveness of unsecured lending-unsecured claims are subordinate to first-priority administrative expenses. Presently, the ambiguity of the law produces considerable inefficiency, as it frequently leads gap debtors and prospective gap creditors to seek court approval of secured lending transactions. ${ }^{68}$ Identifying the optimal solution to this ambiguity de-

67 In addition, if the credit is secured, it has the benefit of reducing the risk-alteration tendency. See Clifford W. Smith, Jr. and Jerold B. Warner, Bankruptcy, Secured Debt, and Optimal Capital Structure: Comment, $34 \mathrm{~J}$ Finance 247, 250 (1979). Restrictions in the security agreement may prevent asset substitution-that is, substituting low-risk assets with higher-risk assets. Id.

68 For example, in In re Shah International, Inc., 94 Bankr 136, 136-37 (Bankr E D Wis 1988), a gap debtor sought and received approval for securing the wages of its attorneys. Legal counsel for prospective gap creditors have been emphatically warned not to lend to gap debtors absent court approval. The Practising Law Institute, for example, sug- 
pends upon one's view of the Code's purposes and limitations as well as of the gap debtor's status.

There are several possible approaches to secured lending during the gap period. The most restrictive approach would strictly apply $\S 362$ 's prohibition on the creation and perfection of liens and thus bar the debtor from secured borrowing. The second view would permit secured borrowing without court approval, but only to the extent of value-narrowly defined pursuant to $\S$ 549(b). The third position allows secured lending without court approval, but with a broader understanding of value than currently prevails. Finally, the fourth position proposes the transformation of the gap debtor into a trustee/debtor-in-possession, with all the consequent powers and duties of a trustee.

A. The Most Restrictive Solution: A Preclusive Interpretation of $\S 362$

Section 362(a)(4) states that the filing of an involuntary petition under $\S 303$ automatically stays "any act to create, perfect, or enforce any lien against property of the estate. ${ }^{.69}$ To the extent this describes a secured loan arrangement, it may require court approval for secured borrowing during the gap period. This position views the transfer-for-value exception of $\S 549(\mathrm{~b})$ as subordinate to $\S 362(\mathrm{~d})$, which requires court approval to lift the automatic stay. This position identifies the Code's principal purpose as the protection of the debtor's assets from destruction by a dishonest or incompetent debtor, discounting the counterproductive effect of debtor paralysis during the gap period.

This restrictive approach should be rejected on both statutory and policy grounds. First, neither the legislative history nor case commentary on $\S 362$ contains any indication that the section was designed to prevent a transfer for value pursuant to $\S$ 549(b). A secured transaction is clearly a transfer for the purposes of the Code. ${ }^{70}$ In addition, the intent of $\S 303(f)$ runs contrary

gests the following guideline for dealing with a gap debtor: "Do not advance credit to an alleged debtor... [during] the 'involuntary gap period' [ ] without obtaining an order allowing the same from the bankruptcy court. The risks far outweigh the potential benefits." Robin E. Phelan, et al, Extending Trade Credit to a DIP: The Second Face of the Devil, in Representing the Trade Creditor and Landlord in Chapter 11 Cases, Commercial Law and Practice Course Handbook No 632 at 153, 263 (Practising Law Institute, 1992). See also Richard F. Broude, Chapter 11 Financing, in ALI-ABA Course of Study: Modern Real Estate Transactions 145, 152-53 (1992).

69 11 USC $\S 362(a)(4)$.

70 In 11 USC § 101, the Code defines "transfer" to mean "every mode, direct or in- 
to this interpretation since it would be impossible for the gap debtor to continue business operations as if the petition had not been filed. ${ }^{71}$ Adoption of the preclusive approach would require obtaining court approval to lift the automatic stay pursuant to $\S$ $362(d)$ before encumbering estate property. Section 362(d), however, was not intended to provide for this contingency; it primarily serves the needs of preexisting secured creditors that are denied adequate protection. ${ }^{22}$

The policy reasons for rejecting this approach are even more compelling. From a commercial perspective, the need to seek court approval impedes the debtor's ability to maintain the goingconcern value of its business. First, there are the transaction costs associated with a hearing. Although these costs may be insignificant, they will prevent consummation of marginally profitable deals. Second, delay poses an additional cost, even where the court will surely approve the deal. The debtor may therefore be foreclosed from entering into profitable enterprises that require a timely response. ${ }^{73}$ Third, there may be great uncertainty as to whether the court will approve the deal. This is bothersome for prearranged contractual agreements and a deterrent to new contracting once the petition has been filed. ${ }^{74}$ Finally, allowing § 362 to trump § 549(b) would effectively paralyze the debtor in many types of business operations. The estate would be frozen as of the time the petitioning creditors filed for bankruptcy, and the debtor's discretion would be more limited in several respects than a debtor-in-possession who, at a minimum, has the operating powers of a trustee. In light of these statutory

direct, absolute or conditional, voluntary or involuntary, of disposing of or parting with property or with an interest in property, including retention of title as a security interest and foreclosure of the debtor's equity of redemption ...."

${ }^{71}$ See text accompanying notes 20-22.

72 See Bankruptcy Law Revision, HR Rep No 95-595, 95th Cong, 1st Sess 343-44 (1977); S Rep No 95-989 at 52-53 (cited in note 20).

${ }^{73}$ This is particularly true for an issuer of commercial paper. As the company's commitments come due, the need to seek court approval will only exacerbate the bankruptcy situation. See note 5 .

74 The combined objections to requiring court approval raise the question of why court approval requirements should be tolerated following a voluntary petition, but not during the gap period. Although the costs are largely the same, the cost-benefit balance is different. First, the ambiguity surrounding the gap period places the gap debtor, in many respects, in a more precarious position. Second, increasing the costs of business operations during the gap period presents opportunities for strategic creditor behavior that are not available in voluntary cases. See text accompanying notes 139-40. Finally, because a substantial percentage of involuntary petitions are ultimately dismissed, see note 17 , it wastes the court's time to sift through the gap debtor's ongoing business operations. 
and policy concerns, this approach has not been embraced by any court and should not be accorded serious consideration. ${ }^{75}$

\section{B. The Prevailing View: In re Roxy Roller Rink Joint Venture and the Restrictive Value Definition}

The prevailing view on secured lending and court approval, as expressed in In re Roxy Roller Rink Joint Venture ${ }^{76}$ is fairly conservative. It does not classify the gap debtor as a trustee, and therefore does not require court approval for secured borrowing. But it does enforce a narrow limit on the debtor's ability to transfer property during the gap period. In Roxy Roller, the court confronted the debtor-as-trustee issue after a gap debtor requested court approval to grant a security interest in property in exchange for cash advances. Roxy was a joint-venture roller rink, in which one of the partners filed a petition to force the joint venture into Chapter 11 bankruptcy. ${ }^{77}$ The filing of the involuntary petition had a detrimental effect on the business, and Roxy was ultimately forced to cease operations due to its lack of liability insurance. ${ }^{78}$

In a prior proceeding, Roxy had sought financing to pay "emergency expenses which must be paid in order for Roxy to remain in a position to reopen ...."79 Pursuant to $\S 364$, the prior court authorized the debtor to grant a security interest, but the gap creditor failed to obtain the final order and did not execute a security interest. The court in Roxy Roller refused to grant

75 There appear to be no reported cases supporting this approach. In standard practice, however, parties regularly seek court approval. It is unclear whether these courts are acting pursuant to $\S 362$ (d) in lifting the automatic stay; $\S 364$, in authorizing the trustee to procure credit, see text accompanying notes $49-54$; or $\S 105$, in invoking the general equitable powers of the court.

7673 Bankr 521 (Bankr S D NY 1987). The Roxy Roller case is the only reported instance where the gap debtor's status as a $\S 364$ trustee has been adjudicated. Roxy Roller is cited in both the practitioner's literature and the scholarly literature. Practitioners accept the Roxy Roller court's view and plan their behavior accordingly. The scholarly literature has mixed views on the court's decision. For support, see David G. Epstein, Steve H. Nickles, and James J. White, Bankruptcy 30 (West, 1993). For criticism, see Paul M. Baisier and David G. Epstein, Postpetition Lending Under Section 364: Issues Regarding the Gap Period and Financing for Prepackaged Plans, 27 Wake Forest L Rev 103, 120 21 (1992).

\footnotetext{
${ }^{77}$ Roxy Roller, 73 Bankr at 522-23.

78 Id at 522.

79 Id at 523.
} 
a request for a nunc pro tunc order, ${ }^{80}$ finding that $\S 364$ did not apply during the gap period. ${ }^{81}$

The court considered deeming the involuntary gap debtor a trustee under $\S 364$, but rejected this option because it felt the freedom Congress granted to gap debtors under $\S 303(f)$ was inconsistent with the duties and obligations imposed upon trustees. ${ }^{82}$ The court also suggested that court approval is not necessary under $\S 549$ to the extent the security interest is transferred for value, ${ }^{83}$ although court approval may provide additional protection for the grant. ${ }^{84}$

Under the Roxy Roller view, $\S 549$ (b) is a clear exception to the automatic stay of $\S 362$. If the transaction meets the requirement of $\S 549(\mathrm{~b})$ that the transfer be for post-petition value, ${ }^{85}$ the bankruptcy trustee will not be able to avoid the transaction. Elaborating on the breadth of this exception, the court in In re 222 Liberty Associates insisted that $\S 549(\mathrm{~b})$ be read very narrowly. "[T]he transferee is obliged to establish that the transfer in issue should be allocated solely to post-petition value or services to protect the transfer." ${ }^{37}$ That court emphasized that transferees have generally been unsuccessful in asserting this defense due to the "substantive and procedural burdens" placed squarely on the transferee. ${ }^{88}$ Such a narrow finding limits the discretion of a debtor-even within the ordinary course of business-in conducting customary commercial relationships that involve buying and selling on credit.

There are two strong, though inconsistent, criticisms of the Roxy Roller approach. The first contends that Roxy Roller provides the gap debtor with insufficient power, while the second

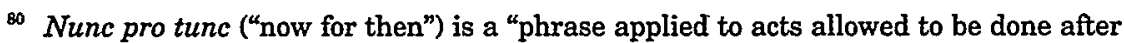
the time when they should be done, with a retroactive effect, i.e., with the same effect as if regularly done." Black's Law Dictionary 1069 (West, 6th ed 1990). For a discussion of the standards used by courts in considering whether to authorize a nunc pro tunc order, see text accompanying notes 141-44.

s1 Roxy Roller, 73 Bankr at 525.

82 Id at 526-27.

83 Id at 525-26.

84 Id at $526 \mathrm{n} 2$.

${ }^{85}$ See 11 USC $\S 549(b)$.

8694 Bankr 381, 382 (Bankr E D Pa 1988), rev'd on other grounds, 110 Bankr 686 (E $\mathrm{D} \mathrm{Pa}$ 1989). Given that the district court's reversal was on other grounds, 222 Liberty Associates remains good authority for the narrow reading of the $\$ 549(\mathrm{~b})$ exception. See, for example, In re Williams Contract Furniture, Inc., 148 Bankr 805, 808-09 (Bankr E D Va 1992).

${ }_{87} 222$ Liberty Associates, 94 Bankr at 382.

88 Id at 384. 
makes the more modest claim that Roxy Roller and the cases following it define "value" too narrowly.

The first criticism begins with the proposition that $\S 364$, far from being a restriction, is a necessary expansion of the powers of the gap debtor, despite the requirement of court approval. Recall that $\S 364$ aids in the essential task of obtaining credit once the petition has been filed. ${ }^{89}$ The trustee is empowered under $\S 364$ to seek court approval to issue debt with different levels of super-priority. In most cases, a lender is unlikely to provide post-petition credit without receiving super-priority. ${ }^{90}$

This view has both a legal and policy component. The legal component interprets $\S 303$ in conjunction with Chapter 11 so as to transform the gap debtor into a debtor-in-possession with the corresponding powers of a trustee. The policy component argues that this is a necessary measure given the precarious position of a gap debtor.

The central legal issue is whether the gap debtor is a "trustee" for the purposes of $\S 364$. In a voluntary Chapter 11 case, the pre-petition debtor normally becomes the post-petition debtor-in-possession, an actor with the powers and responsibilities of a trustee. In a reorganization, the debtor is often in the best position to know the business and the firm's strengths and weaknesses. Therefore, it is in the creditors' best interests to allow the debtor-in-possession to oversee the reorganization. Thus, § 303(f) may affirm that the gap debtor is a debtor-in-possession; only with these enhanced powers will the gap debtor be able to continue in business. ${ }^{91}$

Even if the gap debtor is a debtor-in-possession, not all of the credit-enhancing provisions of $\S 364$ will apply. For purposes of $\S$ 364 priority, there is a distinction between the status of ordinarycourse unsecured debt and all other types of debt. Section 364(a) authorizes the trustee to incur unsecured debt in the ordinary course of business as a first-priority administrative expense. ${ }^{92}$ Under $\S \S 507(\mathrm{a})(2)$ and 502(f), ordinary-course expenses incurred during the gap period are accorded second-priority expense status. ${ }^{93}$.Therefore, it is impossible for both $\S 364(\mathrm{a})$ and $\S 502(\mathrm{f})$ to

\footnotetext{
89 See text accompanying notes 51-54.

so See text accompanying notes 63-67.

it See also text accompanying notes 114-30.

92 See 11 USC \& 364(a).

93 The precise degree of favorability depends on the total asset pool of the estate and the amount of administrative expenses. See text accompanying notes 31-38.
} 
apply at the same time. This suggests that Congress did not intend $\S 364(\mathrm{a})$ to apply to involuntary cases. ${ }^{94}$

The remainder of $\S 364$, however, conceivably could apply to the gap debtor since there are no explicit priority conflicts. Section 364(b) applies to unsecured debt incurred outside the ordinary course of business-debt that otherwise would have the unfavorable priority of pre-petition unsecured debt. ${ }^{95}$ Section 364(c) and (d) authorize the bankruptcy court to grant varying levels of super-priority, including liens secured by estate property, if the trustee is otherwise unable to obtain credit. Section $364(\mathrm{c})$ is the critical provision, because $\S 364(\mathrm{a})$ unsecured debt may not be substantially superior to that provided by $\S 502(f)$. The application of any of $\S 364$ 's subsections, however, is inextricably tied to the gap debtor's status as trustee.

Policy concerns bolster the legal argument for interpreting $\S$ 364 to apply to the gap debtor. Specifically, the court oversight and enhanced priority powers that $\S 364$ allows may enable the debtor to obtain the optimal level of financing during the gap period and into bankruptcy. ${ }^{96}$ Thus, to meet its credit needs both inside and outside the ordinary course of business, the debtor must have the powers of a trustee. The policy reasons for applying $\S 364$, however, do not consider the Roxy Roller view of $\S 549$ or the approach advocated by this Comment, each of which would produce other avenues for post-petition credit. If the debtor can obtain adequate levels of credit through these alternative mechanisms, the credit-enhancing features of trusteeship would create a superfluous complication.

The second major criticism of the Roxy Roller view is the more modest claim that a narrow view of value provides too little flexibility for the gap debtor. The narrow conception of value under Roxy Roller makes it unlikely that a debtor can obtain the optimal level of credit without court approval. ${ }^{97}$ Bankruptcy Rule 6001 provides that "[a]ny entity asserting the validity of a transfer under $\S 549$ of the Code shall have the burden of

9. The same conflict is averted in 11 USC $\$ 503(\mathrm{~b})$, a specific exemption of "claims allowed under section $\S 502(f)^{n}$ (ordinary-course gap claims) from administrative-expense priority.

95 See text accompanying notes $31-43$.

\% Some commentators, however, are skeptical of the courts' ability to make business and financing decisions. See, for example, Triantis, 46 Vand $L$ Rev at 914, 918-19 (cited in note 66 ).

${ }^{97}$ See text accompanying notes 73-75. 
proof."98 This procedural standard immediately raises the ex ante costs of doing business with a gap debtor, because of the risk that the trustee will attempt to avoid the transaction following the order for relief. At a minimum, the transferee must incur the litigation costs of proving that the bargain was for valuable, post-petition consideration. To compensate, the debtor will have to offer a premium to the transferee. Yet, since value is so narrowly defined, the court will likely remit this premium to the estate. For example, in In re Jorges Carpet Mills, Inc., the court allocated a market price to yarn and then forced the gap transferee to reimburse the estate for the difference between the transfer price and the judicially determined market value. ${ }^{99}$ In a secured lending transaction, the securing or paying-off of past indebtedness could constitute the premium. Courts, however, have rejected this type of transaction for purposes of $\S 549(\mathrm{~b})$, which excludes value-securing debt that arose prior to the commencement of the case. Consequently, it is difficult to conceive why a party with notice of the petition would do business with the gap debtor without first obtaining court approval (with the debtor agreeing to pay for the cost of the proceedings).

The narrow view of value also creates problems in the comparison between ex ante and ex post value. ${ }^{100}$ Section 549 does not define value, although the cases make clear that it will be construed narrowly. ${ }^{101}$ Thus, creditors of the estate are likely to contest any transaction that involves the transfer of assets without a clear market price. ${ }^{102}$ How such a transaction should be viewed depends on the purpose of the involuntary petition and its related provisions. If the primary purpose of $\S 549(\mathrm{~b})$ is to protect the gap debtor and good-faith gap creditors, then the conception of value should be ex ante-at the time of the transfer. If, however, the purpose is to preserve the estate, then perhaps the court would assess value ex post-after the order of relief has been granted (at least if the transferred property's value has declined). This debate is particularly relevant to a transfer where the monetary value incorporates a measure of risk of an asset's appreciation or depreciation. A debtor may have an incentive to take on

98 11 USC Appendix, Rule 6001.

99 41 Bankr 60, 66 (Bankr E D Tenn 1984).

100 For a discussion of the distinction between ex ante and ex post value, concluding that ex ante value is the appropriate measure of transfer value for purposes of $\S 549(\mathrm{~b})$, see In the Matter of Texas Research, Inc., 862 F2d 1161, 1163 (5th Cir 1989).

101 See text accompanying notes 86-88.

102 Except, of course, where the net present value of such a suit is negative. 
risky investments if the only way to salvage the business is to cash in on a big investment. ${ }^{103}$ Consequently, in this situation, the court will be forced to evaluate, ex post, the ex ante risk factors associated with such a transfer.

Finally, an overly narrow reading of $\S 549$ imposes a substantial recording burden on gap-period transactions. In In re Butcher, the court disallowed a transfer of $\$ 10,000$ during the gap period where the transferee (an attorney) failed to produce adequate records demonstrating that he in fact performed services during the gap period. ${ }^{104}$ The need to keep records may prove a trivial concern for most attorneys (although apparently not in this case), but only because attorneys generally maintain detailed records of their billable activities.

Record keeping constitutes a more onerous burden, however, in those relationships that normally have no need for such exactitude or in contexts in which it is difficult to apportion value between pre-petition and post-petition transfers. The gap debtor is most likely to do business with parties with whom the debtor has a pre-existing relationship. This is in the best interests of all concerned since the transaction costs of continued operations with these parties are relatively low. However, in ongoing business relationships, there is likely to be outstanding debt and contemporaneous transfers. The precise matching of these exchanges may be extremely difficult and may result in a breakdown in relations. ${ }^{105}$ Finally, continuing the business relationship after the petition has been filed would be dangerous for the non-debtor due to the limited priority protection for unsecured claims as well as the ambiguity surrounding the granting of security interests.

Furthermore, the timing component of the narrow conception of value severely limits its applicability. "The value exchanged for the transfer must be received by the debtor prior to or simultaneously with the transfer." ${ }^{\text {106 }}$ Since the value may not be ex-

${ }^{103}$ Of course, this may be a practice the Code ought to discourage. See text accompanying note $63-67$.

104 69 Bankr 198, 203 (Bankr E D Tenn 1986).

105 The opportunities for disagreement are legion. In particular, the gap debtor may have an implied obligation to notify the third party of the involuntary petition. With or without notification, each party will have conflicting incentives for investing in accurate record keeping detailing the timing and nature of their transactions. Ultimately, a court will have to adjudicate these interests, often after a lengthy delay since priority would not be determined until well after the order for relief.

106 Williams Contract Furniture, 148 Bankr at 808. In Williams, the court allowed the trustee to avoid two post-petition credit card payments made by the involuntary debtor. 
changed for pre-petition debt, this creates an extremely narrow window in which the debtor may operate. Finally, a mere promise was also held to be insufficient value, although it clearly is valuable, particularly considering the trustee's ability to assume executory contracts pursuant to $\S 365$.

In conclusion, the Roxy Roller approach to the extension of gap-period credit is a conservative baseline to the extent it rejects innovative approaches. Although the gap debtor lacks trustee status and therefore may not resort to $\S 364$ credit enhancement, it may grant a security interest without court approval in exchange for value, narrowly construed. The two criticisms of Roxy Roller are inconsistent, but they both point to the same shortcoming: the gap debtor's inability to obtain optimal levels of credit. The gap-debtor-as-trustee position suggests that $\S 364$ and its court-supervised granting of super-priority status may ameliorate this problem. In contrast, the second criticism proposes a broader understanding of value and relies on the marketplace, rather than the courts, to provide the gap debtor with the optimal level of credit. Each of these alternatives will now be considered on its own merits.

\section{Flexible Understanding of Value}

The gap debtor would enjoy the greatest degree of discretion in continuing operations under an approach featuring a broader $\S$ 549(b) understanding of value. Section 549 creates one of the trustee's avoiding powers. ${ }^{107}$ While the other avoiding sections apply to pre-petition transfers, $\S 549$ serves the necessary role of regulating both the debtor-in-possession following the filing of a voluntary Chapter 11 petition and the gap debtor following the filing of an involuntary petition. Section 549(b) excepts gap-period transfers for value from the post-order-for-relief trustee avoiding powers. This exception is crucial to the gap debtor's ability to continue normal business operations without violating the $\S 362$ automatic stay.

Id at 808-09. The court did not accept the credit card company's argument "that value was provided in the form of an extension of credit which allowed the debtor to make purchases through the next billing cycle." Id at 809 . See also In the Matter of Bridges Enterprises, Inc., 44 Bankr 979, 984-85 (Bankr S D Ohio 1984) (voiding the transfer between a creditor and a gap debtor when the creditor cashed a pre-petition check during the involuntary gap period).

${ }_{107}$ See note 28. 
An alternative to the narrow judicial formulation of value under $\S 549$ looks to how other statutory avoiding sections define value. Section 547, which governs preferential transfers, also contains an exception for exchanges that result in new value. ${ }^{108}$ Section 547 defines "new value" as:

money or money's worth in goods, services, or new credit, or release by a transferee of property previously transferred to such transferee in a transaction that is neither void nor voidable by the debtor or the trustee under any applicable law, including proceeds of such property, but [ ] not includ[ing] an obligation substituted for an existing obligation.... ${ }^{109}$

This definition, as interpreted by the courts, would allow greater debtor flexibility since it is more responsive to the type of financing relationships that a financially troubled debtor requires. For example, under this definition, the authorization of new credit in the form of a guarantee constitutes sufficient value to support a transfer. ${ }^{110}$

This definition of value, however, is not so nebulous as to defeat the $\S 547$ purpose of preventing debtor transfers to favored creditors. In one case, an undersecured creditor's forbearance from exercising a default option was deemed not to be new value, since any creditor could claim forbearance while seeking a preferential transfer. ${ }^{111}$ In addition, the definition of value can be limited by a second pre-petition avoiding power: the fraudulent conveyance avoidance of $\S 548$. This section authorizes the trustee to avoid a pre-petition transfer to the extent the debtor "received less than a reasonably equivalent value in exchange for such transfer or obligation."112 This approach places primary focus on $\S 303(f)$ in that its central concern is the continued operation of the gap debtor's business, free from undue restrictions. It seeks equity and efficiency by optimizing the debtor's freedom during the gap period.

${ }^{108}$ See 11 USC $\S 547(c)(1)$ and (4).

10011 USC \& 547(a)(2).

110 See In re Kumar Bavishi \& Associates, 906 F2d 942, 945 (3d Cir 1990) (holding that a guarantee essential to receiving new credit, obtained by payment of pre-existing debt, was "new value" under $\S 547(a)(2)$ ).

11 See Drabkin v A.I. Credit Corp., 800 F2d 1153, 1158-59 (DC Cir 1986).

11211 USC $\$ 548(\mathrm{a})(2)(\mathrm{A})$. For an involuntary case that directly links the $\S 549$ value exception with $\S 548$, see In re Brooklyn Overall Co., Inc., 57 Bankr 999, 1002-03 (Bankr E D NY 1986). 
The obvious criticism of the more permissive interpretation of $\S 549$ value is that it is too generous to gap debtors-entities that probably are on the verge of being declared bankrupt. Extending new credit to the gap debtor may deprive pre-petition creditors of what little value remains in the firm while the debtor squanders the newly acquired funds on risky projects. Thus, a narrower understanding of value is necessary to ensure that secured creditors fulfill their monitoring function.

A second criticism is that a broad view of value substantially increases the risk of camouflaged preferencing as the debtor liquidates assets prior to the order of relief. The debtor and transferee could use $\S 549$ (b) as an absolute shield to avoidance. Additionally, since the gap debtor substantially controls the length of the gap period, the statute of limitations for post-relief avoidance could conceivably lapse. ${ }^{113}$

\section{The Gap Debtor as Trustee}

A fourth approach views the gap debtor as a trustee under both $\S 364$ and other provisions of the Code. ${ }^{114}$ This approach has the advantage of allowing the gap debtor to appear before the court to seek enhanced security (including super-priority liens) for post-petition credit under $§ 364$. However, trustee status would also require the debtor to fulfill all of the fiduciary duties of a trustee. This would limit the debtor's discretion to run the business as if there had been no petition, a condition contrary to $\S 303(f)$.

This argument requires a statutory basis for treating the gap debtor as a trustee. Proponents primarily rely on $\S 1107$, which authorizes a Chapter 11 debtor-in-possession to exercise most of the powers and duties of a trustee. ${ }^{115}$ Section 1101 defines "debtor in possession" to mean any debtor when a trustee has not been appointed. Finally, § 101(13) defines "debtor" as any entity against whom a case has been commenced, not differentiating between a gap debtor and a post-order-for-relief debtor.

113 The statute of limitations for $\S 549$ claims is no longer than two years. See 11 USC $\S 549(\mathrm{~d})$; text accompanying notes 16-17.

114 This approach was discussed earlier as the first refutation to the Roxy Roller view. See text accompanying notes 89-96. For a discussion supporting the treatment of gap debtors as trustees under the $\S 364$ approach, see Baisier and Epstein, 27 Wake Forest L Rev at 118-21 (cited in note 76).

115 This statutory argument is developed in Baisier and Epstein. Id at 120. 
Some courts have relied on this definitional argument to appoint Chapter 11 trustees during the gap period. In Chapter 7 cases, $\S 303(\mathrm{~g})$ specifically authorizes the court to appoint an interim trustee. Although there is no comparable authorization for Chapter 11 cases, the court in In re Professional Accountants Referral Services, Inc. appointed a trustee pursuant to $\S 1104$ prior to the entry of an order for relief. ${ }^{116}$ The court's decision to appoint an interim trustee was influenced by the debtor's improper behavior and by the probability that the debtor would be put into bankruptcy when the petition was adjudicated. ${ }^{117}$

There are two primary criticisms of the $\S 364$ approach. The first, already mentioned, identifies the inconsistency between applying $\S 364$ and $\S 303(f) .{ }^{118}$ This view argues that the duties and powers of the trustee, imposed by $\S 364$ and other Code provisions, would hamper the debtor's ability to conduct its business.

Section 365, for example, authorizes the trustee, subject to court approval, to assume or reject any executory contract or unexpired lease of the debtor. The application of $\S 365$ could cause the gap debtor to lose beneficial contracts, since potential contract partners would be reluctant to contract with a party that can assume or reject the contract. ${ }^{119}$ The use of this power is of course subject to court approval, and a court would likely take a dim view of an attempt to abuse it. However, if the goal is to maximize the value of the estate, the court might be dutybound to approve the action.

An additional complication is the uncertain treatment of executory contracts rejected by the debtor during the gap period following dismissal of the petition. Although the inquiry may be

116142 Bankr 424, 429-30 (Bankr D Colo 1992).

117 Id at 429. Interestingly, the court appointed a trustee despite the debtor's contention that 'the Petitioning Creditors' claims are contested, unliquidated and, therefore, that these Creditors may not be proper petitioning creditors." Id at $429 \mathrm{n} 16$.

For a contrary view, see In the Matter of Beaucrest Realty Associates, 4 Bankr 164, 165 (Bankr E D NY 1980), which held that an interim Chapter 11 trustee could not be appointed during the gap period. The court found that $\S 1104(a)$, which governs the appointment of trustees in Chapter 11 cases, makes no mention of such an interim entity. Id. In addition, Congress explicitly provided for an interim trustee in Chapter 7 cases. 11 USC $\S 303(\mathrm{~g})$. No such provision governs for Chapter 11 . Id. Therefore, the court argued that "to infer such a provision ... is to do violence to sound statutory construction." Id.

18 See text accompanying note 82.

119 The potential applicability of $\$ 365$ raises additional concerns for gap debtors. In In re TS Industries, Inc., 117 Bankr 682, 685 (Bankr D Utah 1990), the court found that those dealing with the debtor cannot protect themselves contractually, because the statute governing the assumption and rejection of executory contracts $(\S 365(e)(1))$ invalidates ipso facto clauses that terminate or modify a contract in the event of bankruptcy. 
fact-specific, such a contract is probably permanently avoided, leaving the contracting party with no recourse save a damages action. ${ }^{120}$ This scenario raises the unattractive possibility of a collusive involuntary petition filed by an outside creditor to free the debtor from an undesired contract. ${ }^{121}$

Section 365 thus highlights the debtor's conflict of interest in acting as a fiduciary for the creditors while fighting the petition and trying to preserve a viable business for the equity owners. ${ }^{122}$ A debtor is duty-bound to avoid contracts disadvantageous to the unsecured creditors. Although rejection of a particular contract might benefit the estate should it enter bankruptcy (because the damage claim would be reduced to pro-rata sharing), it could have a disastrous effect should the debtor stay out of bankruptcy (because the debtor would be responsible for normal contractual damage liability). ${ }^{123}$ Consequently, the gap debtor would be placed in the difficult position of choosing between the fiduciary duties demanded by trustee status and practical business judgment. ${ }^{124}$

The second objection to trustee status for the gap debtor is the resulting divergent treatment of Chapter 7 and Chapter 11 debtors. Chapter 7 does not provide for the debtor-in-possession; therefore, the Chapter 7 debtor is unable to access post-petition credit under $\S 364$. This inequality of treatment may result in a strategic decision by creditors to file under Chapter 7 or 11 based not upon the merits of the case, but rather on the freedom of action the debtor will have during the gap period. ${ }^{125}$

120 This is a largely speculative endeavor since there are few, if any, reported cases in which a gap debtor rejects an executory contract.

121 Courts exacerbate this problem when they adopt a rescission-based view of $\S 365$. See, for example, In re Register, 95 Bankr 73, 74 (Bankr M D Tenn 1989) (allowing the debtor to reject a covenant not to compete as an executory contract).

${ }^{122}$ See Triantis, 46 Vand I Rev at 914 (cited in note 66) for a discussion of judicial treatment of these conflicting fiduciary duties in voluntary debtor-in-possession cases. Triantis also discusses the additional problem of managerial incentives to prevent liquidation so as to retain their jobs. Id at 916-17. Managers may have the incentive to fight an involuntary petition even when the company may belong in bankruptcy.

${ }^{123}$ See Roxy Roller, 73 Bankr at 527 ("It is a sensible statutory scheme to preclude the debtor from taking advantage of the powers of the Bankruptcy Code... while the debtor opposes the entry for an order for relief and when no order for relief may ever be entered.").

${ }^{124}$ See generally Nimmer and Feinberg, 6 Bankr Dev J 1 (cited in note 50).

125 Note, however, that there is already a statutory divergence between Chapter 7 and 11 involuntary petitions regarding the authority to appoint an interim trustee. See 11 USC $\S 303(\mathrm{~g})$; text accompanying notes 116-17. 
Although proponents argue that it is within the debtor's power to mitigate the divergence between Chapters 7 and 11, ${ }^{126}$ none of the proposed steps are truly satisfactory. First, a Chapter 7 involuntary debtor may move to convert the case to Chapter $11^{127}$ and thereby attain the benefits of a debtor-in-possession. This choice, however, is tantamount to capitulating to the involuntary petition since conversion would result in the gap debtor being declared bankrupt and fully subject to the limitations of a debtor-in-possession. ${ }^{128}$ Although the debtor may subsequently move to dismiss the case for cause, dismissal requires the debtor first to demonstrate adequate cause and then to carry the burden of proof. Finally, conversion would likely render moot any defenses or damages action the debtor might have against petitioning creditors under $\S 303(\mathrm{i})$. A second alternative would be for a Chapter 7 gap debtor to move, pursuant to $\S 303(\mathrm{~g})$, for court appointment of an interim trustee. Such action is appropriate, however, only "if necessary to preserve the property of the estate or to prevent loss to the estate." 129 The appointment of an interim trustee also dispossesses the debtor of its ability to manage the business. ${ }^{130}$

There are therefore four approaches to the question of the gap debtor's ability to obtain secured credit. Those solutions granting the debtor considerable power may be faulted for endangering the interests of pre-petition creditors, while those denying the debtor the ability to secure gap-period financing may be challenged on the grounds that they reduce the going-concern value of the enterprise. Determining which approach courts should embrace requires recourse to the policy concerns underlying bankruptcy and the financial circumstances of gap debtors.

\section{IN SUPPORT OF DEBTOR FLEXIBILITY}

This Comment argues that the flexible definition of value discussed in Section II should govern during the gap period. Therefore, under normal conditions, ${ }^{131}$ the gap debtor should be allowed to grant a security interest in property in exchange for

126 These arguments (but not the counter-arguments) are developed in Baisier and Epstein, 27 Wake Forest L Rev at 121-22 (cited in note 76).

${ }^{127}$ See 11 USC $\$ 706(a)$.

12311 USC $\$ 348$.

12911 USC \& 303(g).

130 See text accompanying notes 116-17.

131 "Normal conditions" refers to cases in which the court does not appoint a trustee pursuant to $\$ 303(\mathrm{~g})$. 
value, as defined by $\S 547$. Read broadly, the $\S 549(\mathrm{~b})$ exception for value can serve the same purpose as the $\$ 547$ exception: "to encourage creditors to deal with troubled businesses." 132 Allowing transfers for new value provides the debtor with an opportunity to overcome its insolvency and is therefore beneficial to the estate. ${ }^{133}$ If the court does issue a final order for relief, the value definition should protect creditors from fraudulent conveyances by incorporating the "reasonably equivalent value" standard of $\S 548 .{ }^{134}$ This standard serves the policy goal of continuity in the treatment of voluntary and involuntary petitions.

The proposed approach would allow the gap debtor to seek secured financing during the gap period without court approval. The only limitation on the debtor's financing ability would be the willingness of creditors to infuse "new value" into the business. Such willingness would reflect the merit of the projects the debtor proposes to accomplish and the quality of collateral that it can offer. Three additional reasons, outlined below, support this reading of the Code.

\section{A. Congressional Intent}

Section 549 authorizes transactions creating post-petition value, and $\S 303(f)$ authorizes the gap debtor to continue business as normal. Both of these broad statements express a clear intent, ${ }^{135}$ yet they cause ambiguities in practice. The prevailing definition of value is derived not from the Code, but from a procedural Bankruptcy Rule which applies generally to all post-petition transfers. ${ }^{136}$ This rule has the substantive effect of frustrating the liberal intent of the drafters of $\$ \S 303(\mathrm{f})$ and $549(\mathrm{~b})$.

132 See In re Bellanca Aircraft Corp., 850 F2d 1275, 1280 (8th Cir 1988), quoting In re Almarc Manufacturing, Inc., 62 Bankr 684, 687-88 (Bankr N D Ill 1986).

${ }_{133}$ See In re American International Airways, Inc., 56 Bankr 551, 554-55 (E D Pa 1986) (finding payment for new inventory is not a preferential transfer).

${ }^{134}$ The reasonable-equivalence standard is more conducive to the gap debtor's business situation than the narrow definition of value since it does not insist on a dollar-fordollar accounting. Instead, the standard depends on all the facts and circumstances of each case, including the fair market value of the exchange and whether the parties were engaged in an arm's length transaction. See In the Matter of Bundles, 856 F2d 815, 824 (7th Cir 1988). See also In re Chase \& Sanborn Corp., 904 F2d 588, 594-95 (11th Cir 1990) (finding that loan proceeds in exchange for a guarantee of a much greater dollar amount can be reasonably equivalent value). For a discussion of the applicability of $\S 548$ 's value standard to $\S 549$, see Brooklyn Overall, 57 Bankr at 1002-03.

${ }^{135}$ See text accompanying notes 22-23, 27-30.

13611 USC Appendix, Rule 6001. 
Section 362 provides some insight into Congress's view of the gap debtor. In In re Oxford Dev., Ltd., the court considered the benefits the automatic stay offers to gap debtors. ${ }^{137}$ The court observed: "It can only be assumed that Congress felt putative debtors should be free from all other concerns while the question of bankruptcy is at issue thereby allowing the debtor to concentrate exclusively on that one issue."138 This reading of $\S 362$ supports a liberal treatment of the debtor's business relationships during the gap period. Courts, however, have bypassed such an integrated approach in favor of piecemeal treatment-adjudicating individual disputes over specific Code sections in isolation. The gap debtor, however, is accorded special treatment throughout the Code, and courts should reflect this implicit congressional policy directive when they interpret the individual provisions. In short, to the extent the debtor avoids fraudulent or preferential transactions, business should be allowed to continue as normal.

\section{B. Efficiency}

1. The costs of ambiguity.

The prevailing Roxy Roller understanding of value imposes significant costs. Ambiguity encourages strategic gamesmanship because the creditor can exert significant leverage over the more vulnerable debtor. ${ }^{139}$ The more the debtor fears the consequences of the involuntary gap period, the more likely it is to capitulate to creditor demands, thus encouraging more threats by other creditors. ${ }^{140}$ Conversely, ambiguity may also reduce the incen-

137115 Bankr 216 (Bankr W D Mo 1990).

138 Id at 217.

139 This occurs where a petitioning creditor files so as to prevent the debtor from paying a third party. See, for example, Algemene Bank Nederland, N.V. v Hallwood Industries, Inc., 133 Bankr 176, 178 (W D Pa 1991). Enhancing the debtor's ability to pay gap creditors contemporaneously would discourage this type of opportunism. Additionally, effective enforcement of $\S 303(i)$ sanctions would be helpful.

In extreme cases, the court can mitigate the damage from a strategic filing of the involuntary petition through abstention pursuant to 11 USC $\$ 305(a)(1)$. See, for example, In the Matter of Investment Corporation of North America, 39 Bankr 758, 759 (Bankr S D Fla 1984) (dismissing an involuntary petition where disgruntled creditors were seeking to gain control of the debtor's business).

140 The threat of involuntary bankruptcy may be used not only for strategic advantage by creditors, but by limited partners as well. See Note, What Do You Mean My Partner. ship Has Been Petitioned Into Bankruptcy?, 19 Fordham Urban I J 833, 833-34, 840-46 (1992). 
tives for proper involuntary filing because errors in court approval can dissipate the estate during the gap period.

There are two types of errors that may result from ambiguity in the court approval requirement. The first type arises when a gap debtor unnecessarily seeks court approval. This is a common occurrence, yet if the Roxy Roller court is correct (and § 364 thus does not apply to gap debtors), the court may lack authority to approve the lending transaction. This not only proves costly to the debtor because of attorneys' fees and lost opportunities, but also wastes limited judicial resources.

The second type of error occurs when the debtor does not seek court approval, but the court later decides that approval was necessary. To preserve the transaction, the gap creditor or gap transferee must seek nunc pro tunc approval of the claim. It is extremely difficult, however, to obtain such relief. In In re J.L. Graphics, Inc., the court decided that it should never authorize such retroactive approval under the current Bankruptcy Code. ${ }^{141}$ Courts are apparently hostile to such "fall back"142 treatment because they prefer that parties protect their rights ex ante. Some courts will grant nunc pro tunc relief only when the claimant can meet a three-part standard that requires: (1) that the court would have granted approval had the application been timely; (2) that no creditor has been hurt by the continuation of the business allowed by the loan; and (3) that the debtor and creditor honestly believed that they could enter into the loan transaction without approval. ${ }^{143}$ Other courts require even more "compelling" or "extraordinary" circumstances than those necessary to fulfill the above standard. ${ }^{144}$ Since ex post court approval is unlikely, disadvantaging one individual creditor could potentially undo even a value-increasing transaction. Such preference for an individual creditor over the estate as a whole directly contradicts the purpose of the Bankruptcy Code.

14162 Bankr 750, 755-56 (Bankr D NH 1986).

${ }^{142}$ See In re Photo Promotion Associates, Inc., 87 Bankr 835, 840-41 (Bankr S D NY 1988).

${ }_{143}$ See In re Lite Coal Mining Co., 122 Bankr 692, 695-96 (Bankr N D W Va 1990), citing In re American Cooler Co., Inc., 125 F2d 496 (2d Cir 1942).

${ }_{144}$ See, for example, In the Matter of Grand Valley Sport \& Marine, Inc., 143 Bankr 840, 851-52 (Bankr W D Mich 1992) (holding that in addition to the Lite Coal requirements, the "equities must strongly favor the creditor and there must be an 'absence of prejudice to any interested party"). 
2. Transaction costs of seeking court approval.

The transaction costs of seeking court approval are also significant-particularly to a credit-starved debtor. In In re Shah International, Inc., the court granted approval for the debtor to execute mortgages as security for payment of its attorneys. ${ }^{145}$ Although the transaction was admittedly essential to the successful defense of the estate, the court added extensive terms and conditions to the exchange: continuing oversight of the fee structure with periodic reporting requirements, restricting the strength of the security agreement to the administrative expense level, prohibiting cross-collateralization, and providing for notice to other creditors. ${ }^{146}$ Since these measures involved attorneys' fees, they may have been justified and within the ordinary sphere of the bankruptcy court. However, a court will likely extend similar treatment to any business arrangement where a gap debtor seeks court approval. Therefore, high transaction and ambiguity costs make it more difficult to find businesses willing to conduct operations with the gap debtor. The flexible approach, therefore, maximizes the value of the estate by allowing the gap debtor to seek new credit free from the burdens of repeatedly obtaining court approval. Protection for pre-petition creditors will come from the gap lenders' incentives, court action in extraordinary cases, and the "reasonably equivalent value" component of the flexible value standard.

\section{Equity and the Inadequacy of Corrective Measures}

In addition to efficiency, the Code seeks equity for the legitimate interests of debtors and creditors. The restrictions placed on the gap period increase the risk to financially vulnerable debtors of threatened or actual bad faith filings. These filings disturb equity in two ways. First, a bad faith filing may harm the debtor unjustly by preventing operations during the gap period, thereby causing loss of the business's going-concern value. Second, the threat of bad faith filings inequitably advantages one class of creditors-those willing to threaten an involuntary petition-at the expense of all other creditors.

There are two ways the Code may approach the problem of frivolous or bad faith filings. One way is to deprive the petitioners of any coercive bargaining advantage from filing a petition by

${ }^{145} 94$ Bankr 136, 138-39 (Bankr E D Wis 1988).

146 Id at 139. 
ensuring that the gap debtor may continue business operations. The second way is to deter creditors from bad faith filings with compensatory and punitive damage awards. Although a combination of the two approaches may be essential to prevent undesirable petitions from being filed, policy makers must also take care to avoid deterring appropriate involuntary filings. If a filing is appropriate, the petitioning creditors should not be deterred by the fact that the debtor will continue to have opportunities to raise credit for the estate. Enhanced penalties for unsuccessful and bad faith petitions, however, may deter even well-intentioned creditors by exacerbating the collective action problem. ${ }^{147}$

For a variety of practical reasons, the corrective measures enumerated in $\S 303(i)$ may prove inadequate to protect the gap debtor from petition filings that are not in the joint interests of all creditors. The courts have been willing to impose damages in cases of bad faith. In In re Wavelength, Inc., the court imposed punitive damages for a frivolous, bad faith filing of an involuntary petition, using an objective standard that asked what a reasonable person would have believed concerning the debtor's solvency. ${ }^{148}$ Such a standard, although the most practical rule, is fraught with the danger of inconsistent application ${ }^{149}$ (as is any factual determination subject to the clearly erroneous standard of review). Additionally, the necessary bad faith may well be difficult to prove, as long as the creditor can show some evidence of the debtor's financial difficulty. In In re Turner, for example, the court applied Bankruptcy Rule 9011 and held that the petitioning creditors had at least an arguable Chapter 7 case and were not primarily maliciously motivated. ${ }^{150}$ Thus, $\S 303(i)$ will not necessarily prevent threats of filings that cause the debtor to make a preferential transfer or otherwise behave in a suboptimal manner. ${ }^{151}$

147 Raising the costs of filing for an individual petitioning creditor also increases the incentive to free ride off the efforts of another creditor.

${ }_{148} 61$ Bankr 614, 619-20 (9th Cir BAP 1986). See also Camelot, Inc. $v$ Hayden, 30 Bankr 409, 411 (E D Tenn 1983) (awarding compensatory and punitive damages for a bad faith filing); In re Godroy Wholesale Co., Inc., 37 Bankr 496, 501 (Bankr D Mass 1984) (finding that punitive damages may be awarded).

149 See 11 USC Appendix, Rule 8013.

15080 Bankr 618, 623-24, 628 (Bankr D Mass 1987).

151 One example of this conflict arises in the context of a supplier of commercial paper whose business creditors are contractually restricted from filing an involuntary petition. Other creditors that have the power to make such threats will have a favored position as debts come due. It is unclear, however, whether they are the most economically important creditors to pay off. 


\section{CONCLUSION}

The gap debtor's current status is unclear due to conflicting statutory provisions and the disjointed analysis employed by the bankruptcy courts in interpreting individual provisions of the Code-an analysis without reference to the interrelationship of the statute and considerations of equity and efficiency. The debtor's ability to conduct business, particularly to grant security interests, during the gap period is thus shrouded in uncertainty. The inability of the debtor to be assured of continued viability in the face of an involuntary bankruptcy proceeding undermines the policies animating the Bankruptcy Code.

This Comment suggests an alternative to the present ambiguity, one that provides the debtor with a full opportunity to obtain adequate credit during the gap period without the handicap of court oversight. This approach requires only a slight modification of the prevailing view: substituting the established definition of value from $\S 547$ in place of the judicially created narrow definition of value. Although this refinement increases the risk of debtor misbehavior, the unique qualities of the gap period justify that risk because it best accords with congressional intent and the interests of both debtors and creditors. 
. 